\title{
Habitat preference and spatial distribution model of threatened species Saurauia microphylla in Mt. Slamet, Central Java, Indonesia
}

\author{
HENDRA HELMANTO ${ }^{1,2}$, NISYAWATI ${ }^{1, \bullet}$, IYAN ROBIANSYAH ${ }^{2}$, RIZMOON NURUL ZULKARNAEN $^{2}$, \\ NABELA FIKRIYYA ${ }^{1}$ \\ ${ }^{1}$ Department of Biology, Faculty of Mathematics and Natural Sciences, Universitas Indonesia. J1. Lingkar UI, Depok 16424, West Java, Indonesia \\ ${ }^{2}$ Research Center for Plant Conservation and Botanic Gardens (Bogor Botanic Gardens), Indonesian Institute of Sciences. Jl. Ir. H. Juanda No. 13, Bogor \\ 16122, West Java, Indonesia. Tel./fax.: +62-251-8322-187, ^email: nsywt@yahoo.com
}

Manuscript received: 8 April 2020. Revision accepted: 8 June 2020.

\begin{abstract}
Helmanto H, Nisyawati, Robiansyah I, Zulkarnaen RN, Fikriyya N. 2020. Habitat preference and spatial distribution model of threatened species Saurauia microphylla in Mt. Slamet, Central Java, Indonesia. Biodiversitas 21: 2946-2954. Saurauia microphylla de Vriese has the potentials for medicinal uses, yet it is listed in the IUCN Red List under Vulnerable status. The natural population of this species is only found in highlands one of which is in Mount Slamet, Central Java, Indonesia. This study aims to determine the population structure, habitat preference and predicted spatial distribution of S. microphylla in the Mount Slamet area. The method used was purposive sampling by establishing 103 observation plots with size of $20 \times 20 \mathrm{~m}^{2}$ for each plot. The research parameters recorded were abiotic variables and biotic associations. Data were analyzed using Principal Component Analysis (PCA) to determine the most influencing environmental factors on the presence of $S$. microphylla. Species association of $S$. microphylla was analyzed using the Jaccard index equation. Spatial distribution model was analyzed using Maxent (Maximum Entropy) software. The results showed that $S$. microphylla populations were found in highland forest areas with elevations of $1689-2265 \mathrm{~m}$ above sea level, slope of 3-40', temperature of $16^{\circ}-26^{\circ} \mathrm{C}$, air humidity of $49.3-90 \%$, soil $\mathrm{pH} 5.8-7$, soil moisture $5-70 \%$ and canopy cover of $0-92 \%$. Our analyses revealed that elevation is the most influential factor in the presence of $S$. microphylla. There are 20 tree species which found around $S$. microphylla habitat with 4 species have significant association with the species. The spatial distribution model showed that $S$. microphylla spread across all the slopes of Mount Slamet with the southwestern slope was predicted had the most extensive habitat suitability for the species and become smaller to the north, east, and south slopes.
\end{abstract}

Keywords: Habitat preference, Mount Slamet, Saurauia microphylla, spatial distribution

\section{INTRODUCTION}

Saurauia is a member of the family Actinidiaceae. Saurauia has the origin distribution in subtropical and tropical areas (Briggs 2011), including Indonesia (Walter and Gillett 1998). Several new Saurauia species have been discovered (Takeuchi 2008; Conn and Damas 2013) with some of them have compounds potential for uses (Rafidah 2013; Briggs 2015). The leaf extraction of several Saurauia species is known to contain phenolic compounds, alkaloids, flavonoids, glycosides, O-glycosides, terpenoids, carbohydrates, steroids, reducing sugar, tannins, phlorotannins and saponin (Ahmed et al. 2013). Saurauia has anticancer properties (Muaja et al. 2013), anti-oxidants (Kadji et al. 2013), anti-diabetes drugs, and cholesterol (Sitorus 2015; Hutapea 2018), and been used for traditional medicine to treat several diseases (Ahmed et al. 2016).

Saurauia microphylla is one of several Saurauia species that is included in the IUCN Red List and is under the category of vulnerable IUCN (2020). Besides $S$. microphylla, there are several Saurauia species in Indonesia listed in the IUCN Red List in endangered species, including S. bracteosa (vulnerable), S. cauliflora (vulnerable), S. lanceolata (vulnerable) and S. bogoriensis (critically endangered).
Saurauia microphylla has a shrub-tree shaped habitus. The species has lanceolate leaves with a leaf length of 10$20 \mathrm{~cm}$. S. microphylla has serrated leaf edge with a pointed tip. The young leaves are green-reddish and hairy. $S$. microphylla has much fruit on tree branches and leaf axillar with short fruit stem. As Saurauia in general, $S$. microphylla has are hermaphroditic and unisexual flowers. White stamens with yellow anthers. Berries-capsule fruit flowers shaped, slimy, seedy, wingless, dashed endosperm, embryo straight, or slightly curved (Dressler and Bayer 2004).

Mount Slamet in Central Java Province, Indonesia is one of the S. microphylla natural distribution area. Based on previous study, S. microphylla was discovered in the eastern slope of the Mount Slamet area (Soemarno and Girmansyah 2012). Purnomo et al. (2015) reported the existence of several types of Saurauia in several regions of Mount Slamet at an altitude of 700-1100 m above sea level (m asl). The forest in Mount Slamet has a high diversity of plants across several vegetation zones (Soemarno and Girmansyah 2012), which likely provides a good habitat for S. microphylla. However, there are several factors that can disturb the habitat for S. microphylla in this area. For example, Mount Slamet is one of the active volcanoes in Indonesia (Vukadinovic and Sutawidjaja 1995). Soemarno 
and Girmansyah (2012) reported land conversion in Mount Slamet from forest into agriculture and mixed garden.

The main causes of plant extinction throughout the world are habitat fragmentation and disturbances (Sala et al. 2010). Conservation of S. microphylla in Mount Slamet area requires some information related to population, habitat preferences, and location of species distribution. Research on population, habitat preferences, and prediction of S. microphylla distribution in Mount Slamet area has never been done before. Intense pressures on land use and management require up-to-date information on the status of native species (Keith 2000). Therefore, this research becomes important to be done as an effort to support the $S$. microphylla conservation.

This study aims to determine the population, habitat preferences, and predicted spatial distribution of $S$. microphylla in Mount Slamet region, Central Java, Indonesia. The results of the study can be used as baseline information for the conservation of S. microphylla and to prevent local extinction of the species in Mount Slamet region.

\section{MATERIALS AND METHODS}

\section{Study area and period}

This study was carried out in the Mount Slamet forest area, Central Java, Indonesia, more specifically around the hiking trails on the four slopes (northern, eastern, southern and western). Data collection began from the starting point of the hiking trail and ended at the altitude at which there was no longer $S$. microphylla founded. The southern slope was started from Baturraden area at the point $S 7^{\circ} 18^{\prime} 14.43^{\prime \prime}$ and $\mathrm{E} 109^{\circ} 13^{\prime} 48.99^{\prime \prime}$ at $\pm 916 \mathrm{~m}$ asl, the eastern slope was started from the Bambangan village at $S 7^{\circ} 13^{\prime} 33.72^{\prime \prime}$ and $\mathrm{E}$ $109^{\circ} 15^{\prime} 51.45^{\prime \prime}$ at $\pm 1485 \mathrm{~m}$ asl, the western slope was started from the Kalikidang village $S 7^{\circ} 16^{\prime} 04.72^{\prime \prime}$ and E $109^{\circ} 08^{\prime} 34.91 "$ at $\pm 1850 \mathrm{~m}$ asl, the northern slope was started from the Guci area at $\mathrm{S} 7^{\circ} 11^{\prime} 50.14 "$ and $\mathrm{E}$ $109^{\circ} 09^{\prime} 59.02^{\prime \prime}$ at $\pm 1176 \mathrm{~m}$ asl. Map of research locations can be seen in Figure 1. Data collection in the field and identification of species were carried out in 2019.

\section{Sampling methods}

The data of population and habitat preferences were collected using purposive sampling method (MuellerDombois and Ellenberg 1974) with total 103 plots on different four slopes. Parameters recorded for the population data were number of individuals, stem diameter (dbh), and height of $S$. microphylla plant. Habitat preferences data were taken based on the presence (42 plots) and absence (61 plots) of $S$. microphylla in the observation plot. The environmental parameters included elevation recorded by GARMIN GPSMAP 78S, slope and aspect taken using Suunto® Tandem Global Compass/Clinometer, canopy cover recorded using Habitapp (Zulkarnaen et al. 2019), soil pH and soil moisture taken by Takemura DM 5 Soil tester. Trees that grew around the habitat of $S$. microphylla were inventoried and identified to determine the association of tree species with a plot size of $20 \times 20 \mathrm{~m}^{2}$.

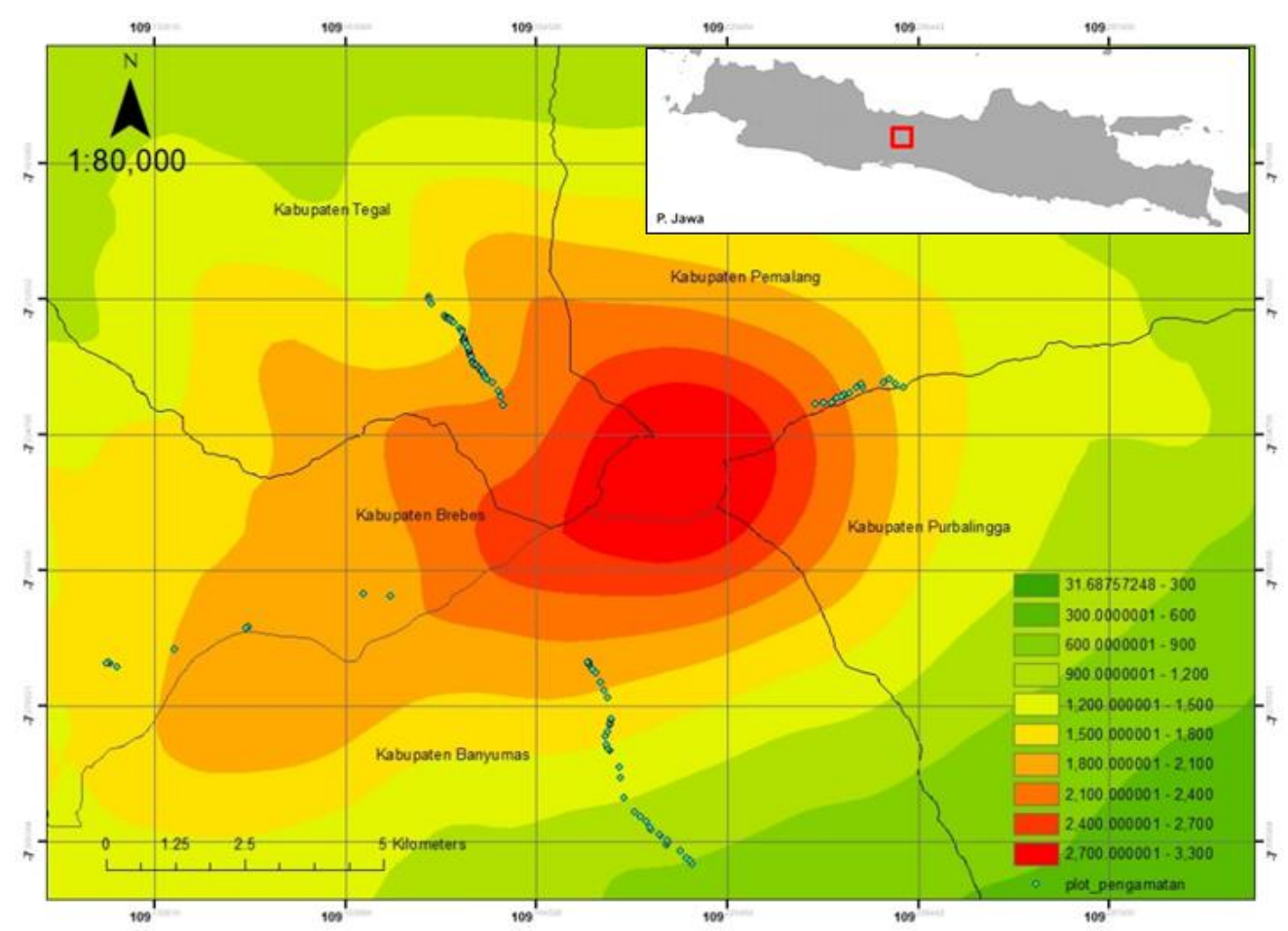

Figure 1. Research locations (green dots) of S. microphylla habitats along the four slopes in the Mount Slamet area, Central Java, Indonesia 


\section{Data analysis}

Saurauia microphylla population data were analyzed based on number, dbh, and height of individuals. Each individual was classified into 4 growth phases (i.e. seedlings, sapling, poles, trees) based on plant height and diameter. Mueller-Dombois and Ellenberg (1974) classified seedling= height $<1,5 \mathrm{~m}$; sapling $=$ height $\geq 1,5 \mathrm{~m}$ and dbh $<10 \mathrm{~cm}$; poles $=$ height $\geq 1,5 \mathrm{~m}$ and $\mathrm{dbh} 10-20 \mathrm{~cm}$; trees= height $\geq 1,5 \mathrm{~m}$ and $\mathrm{dbh} \geq 20 \mathrm{~cm}$. The analysis of habitat preference was performed using the Principle Component Analysis (PCA) method using IMB SPSS Statistics 26 for Windows. PCA analysis was performed to determine the effect of environmental parameters on the presence of $S$. microphylla and it is one of the most commonly used tools in the analysis of ecological data (Franklin 1995; PeresNeto 2003). SPSS software is one software that can be used for data analysis related to the habitat preferences of a species (Robiansyah and Davy 2015).

The association between S. microphylla and other tree species was analyzed with a $2 \times 2$ contingency table for each species pair. Furthermore, it was tested using the ChiSquare test (Ludwig and Reynolds 1988). The association value between Saurauia and other plant species was calculated using the Jaccard Index. The direction of the association was determined by comparing the observed value for $\mathrm{x}(\mathrm{F}(\mathrm{x}))$ with the expected value $(\mathrm{E}(\mathrm{x}))$. If $\mathrm{F}(\mathrm{x})\rangle$ $\mathrm{E}(\mathrm{x})$, then the association is positive, while if $\mathrm{F}(\mathrm{x})<\mathrm{E}(\mathrm{x})$, then the association is negative (Ludwig and Reynolds 1988).

Spatial distribution model analysis was performed using Maxent Software v3.3, ArcMap 10.3 (ArcGIS), and QGIS 3 software. Leathwick et al. (2006) reported that MaxEnt is one of the modeling tools in spatial distribution that has good performance in prediction accuracy. Modeling was done by combining several maps/spatial datasets of various parameters. The parameters of elevation, aspect, and slope were obtained from a contour map obtained from the Rupa Bumi Indonesian (RBI) map and National Digital Elevation Model from Geospatial Information Agency (Badan Informasi Geospatial). Climate parameters in the form of maximum temperature, minimum temperature, maximum rainfall, minimum rainfall, and average rainfall were taken from the Worldclim database (Worldclim 2020). The results of the analysis were used to predict the presence of S. microphylla in the Mount Slamet area.

\section{RESULTS AND DISCUSSION}

\section{Population structure and habitat preference}

The results showed that S. microphylla was found on the four slopes of Mount. A total of 145 individuals of $S$. microphylla was recorded at 42 observation plots. Sapling phase dominated the population of S. microphylla with 89 individuals, followed by pole phase with 39 and tree phase with 14 (Figure 2). The seedling phase was the lowest with 3 individuals.

The analysis of habitat preference was generated from 103 observation plots in which 42 plots had the presence of S. microphylla while the other 61 plots had the absence of the species. Environmental data on the 42 presence observation plots showed the tendency of habitat $S$. microphylla. In general, the population of this species was found at altitude of 1689-2265 m asl, slopes of approximately $3-40^{\circ}$, temperature during the day of $16-$ $27.2^{\circ} \mathrm{C}$, humidity of $49.3-90 \%$, canopy cover of $0-92 \%$, soil $\mathrm{pH}$ between 5.8-7 and soil moisture between $15-70 \%$ (Table 1).

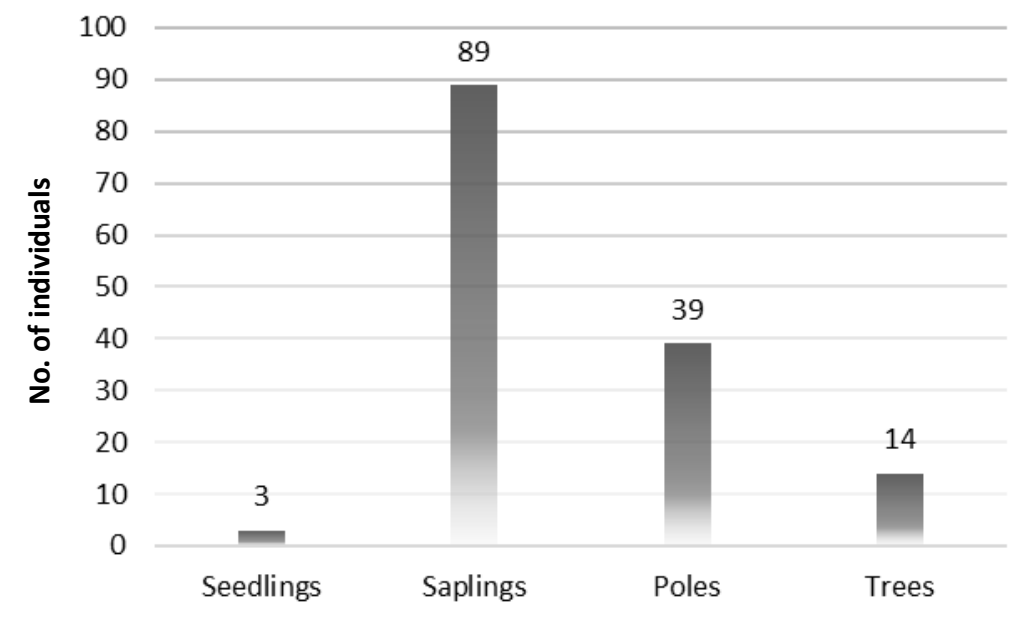

Figure 2. The population structure of S. microphylla in Mount Slamet, Central Java, Indonesia area based on the growth phase (seedling $=$ height $<1.5 \mathrm{~m}$; sapling = height $\geq 1.5 \mathrm{~m}$ and $\mathrm{dbh}<10 \mathrm{~cm}$; pole $=$ height $\geq 1.5 \mathrm{~m}$ and dbh $10-20 \mathrm{~cm}$; tree $=$ height $\geq 1.5 \mathrm{~m}$ and dbh $\geq 20$ $\mathrm{cm}$.) 
Table 1. The results of measurement data of environmental factors in S. microphylla habitats in Mount Slamet area, Central Java, Indonesia

\begin{tabular}{lllll}
\hline $\begin{array}{l}\text { Environmental } \\
\text { parameters }\end{array}$ & Min & Max & Mean & $\begin{array}{l}\text { Standard } \\
\text { deviation }\end{array}$ \\
\hline Elevation (m asl) & 1687 & 2265 & 1942.64 & \pm 127.83 \\
Slope $\left({ }^{\circ}\right)$ & 3 & 40 & 24.45 & \pm 9.13 \\
Temperature $\left({ }^{\circ} \mathrm{C}\right)$ & 16 & 27.6 & 20.50 & \pm 3.51 \\
Soil pH & 5.8 & 7 & 6.59 & \pm 0.35 \\
Soil Humidity $(\%)$ & 15 & 70 & 39.98 & \pm 15.37 \\
Humidity $(\%)$ & 49.3 & 90 & 67.59 & \pm 11.42 \\
Canopy cover $(\%)$ & 0 & 92 & 55.05 & \pm 22.43 \\
\hline
\end{tabular}

The result of Principal Component Analysis (PCA) across all observation plots (i.e. 103) showed that the presence and absence of $S$. microphylla were influenced by two-factor interactions. The first interaction was influenced by elevation (0.844), soil $\mathrm{pH}(0.842)$, and humidity (0.732 ). While the second-factor interaction was influenced by slope $(-0.805)$ and canopy cover $(0.727)$. The KaiserMeyer-Olkin sampling size adequacy value is 0.60 and the significance of Bartlett's Test of Sphericity <0.001. These values indicate that the results of the PCA analysis can be received statistically with the condition that the KaiserMeyer-Olkin value $>0.5$ and significance $<0.01$ (Franklin 1995). The Eigen variant value from the analysis was $67.303 \%$. This shown that the environmental factors analyzed have an important role approximately $67.303 \%$ while $32.697 \%$ are influenced by other factors. Eigenvalues> $50 \%$ also indicate the distribution of $\mathrm{S}$. microphylla spread evenly. Species distribution is be spread evenly if the Eigenvalue is more than 50\% (Jongman et al. 1987; Kent and Coker 1992; Franklin 1995; Peres-Neto 2003).

The results of PCA on the 42 presence plots showed two-factor interactions that affect the distribution of the species. The first environmental factors interaction was humidity (0.798), slope (-0.730), and canopy cover $(0.618)$. The second-factor interaction was elevation (0.829) and soil $\mathrm{pH}$ (0.824). The Kaiser-Meyer-Olkin sampling adequacy value was 0.514 and Bartlett's Test of Sphericity significance is 0.008 . The Eigenvalue of the analysis results was $61.255 \%$. Each environmental parameter has a value range of- 1 to 1 . The maximum value of each component is 1 which means that the factor is very influential. While the 0 value has the meaning that the factor has no effect. Positive values indicate the existence of a direct relationship with a parameter to the presence of factor interactions and the presence of species. Meanwhile, negative values indicate an inverse relationship to factor interactions and species presence (Franklin 1995; PeresNeto 2003).

Figure 3 shows the distribution of all 103 plots with the presence or absence of $S$. microphylla in relation to environmental factors interact. The figure indicates that the larger circle (i.e. plot with the presence of $S$. microphylla) is more distributed above the regression line 1 and on the right side of the regression line 2 . These results suggest that S. microphylla has a tendency to grow in environment with higher elevation, higher soil $\mathrm{pH}$, lower humidity, lower slope, and denser canopy cover.

Figure 4 shows the distribution of plots with the presence of $S$. microphylla in relation to environmental factors interact. From the 42 presence plots, it can be seen that the distribution of the larger circles is more distributed above the regression line 1 and on the left of the regression line 2. These results suggest that a larger population of $S$. microphylla tends to be found at locations with higher humidity and canopy cover density. S. microphylla also more presence in lower slopes, elevations, and soil $\mathrm{pH}$ conditions.

\section{Association of S. microphylla with other tree species}

The analysis of association revealed that $S$. microphylla has association with 18 tree species belong to 13 families (Table 3). Chi-square test showed that there were three species that were significantly associated with 95\% confidence level, i.e. Bellucia axinanthera (Melastomataceae), Lepisanthes rubiginosa (Sapindaceae) and Saurauia pendula (Actinidiaceae). B. axinanthera has Jaccard index value by $0.3333, L$. rubiginosa 0.1628 , and S. pendula 0.1219. Kurniawan and Parikesit (2008) classifies the strength of the association based Jaccard index values into four levels association, which are very high (0.75-1.00), high (0.49-0.74), low (0.48-0.23) and very low $(<0.22)$.

Table 2. Results of principal component analysis (PCA) on environmental factors of the habitat of S. microphylla in Mount Slamet area, Central Java, Indonesia

\begin{tabular}{ccccc}
\hline \multirow{2}{*}{ Factor } & \multicolumn{2}{c}{ All plots (presence and absence) } & \multicolumn{2}{c}{ Presence plots only } \\
\cline { 2 - 5 } & $\mathbf{1}$ & $\mathbf{2}$ & $\mathbf{1}$ & $\mathbf{2}$ \\
\hline Elevation & $\mathbf{0 . 8 4 4}$ & 0.240 & 0.070 & $\mathbf{0 . 8 2 9}$ \\
Slope & 0.035 & $\mathbf{- 0 . 8 0 5}$ & $\mathbf{- 0 . 7 3 0}$ & -0.112 \\
Soil pH & $\mathbf{0 . 8 4 2}$ & -0.095 & -0.111 & $\mathbf{0 . 8 2 4}$ \\
Humidity & $\mathbf{- 0 . 7 3 2}$ & 0.404 & $\mathbf{0 . 7 9 8}$ & -0.338 \\
Canopy cover & -0.030 & $\mathbf{0 . 7 2 7}$ & $\mathbf{0 . 6 1 8}$ & 0.018 \\
\hline
\end{tabular}

Note: Analysis of the Varimax rotation method by Kaiser normalization: (1) For all plots, the Eigenvalue was $67.303 \%$, the adequacy value of Kaiser-Meyer-Olkin sampling was 0.60 and the significance of Bartlett's Test of Sphericity was $<0.001$. The presence plots only had an Eigenvalue value of $61.255 \%$, the adequacy value of Kaiser-Meyer-Olkin sampling of 0.514 and the significance of Bartlett's Test of Sphericity of 0.008 . 


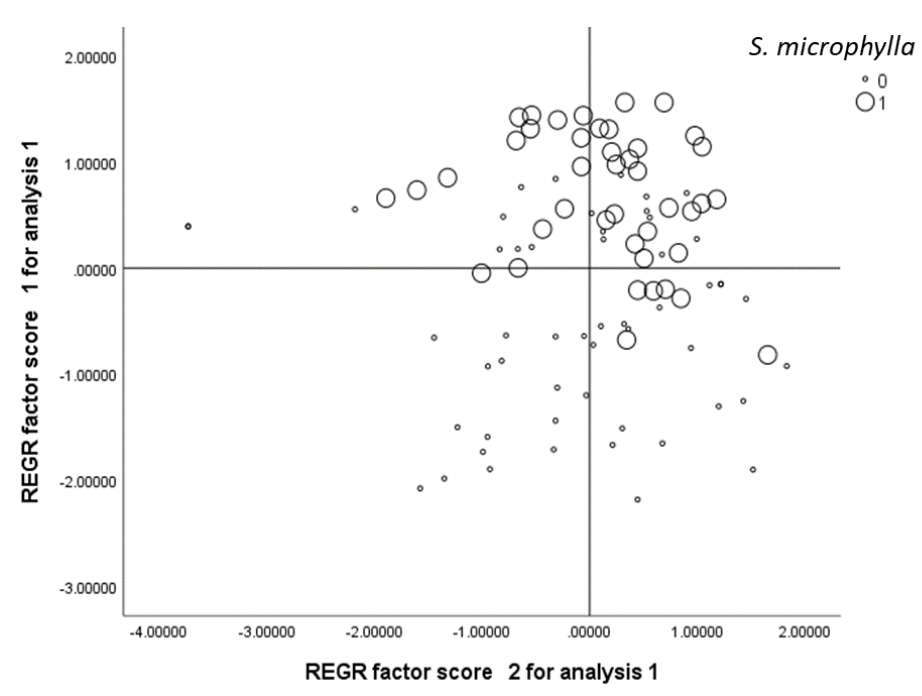

Figure 3. The distribution of plots with the presence (big circle=1) and absence (small circle $=0$ ) of $S$. microphylla related to environmental factors interact. The plot with $S$. microphylla presence is indicated by circle with larger size

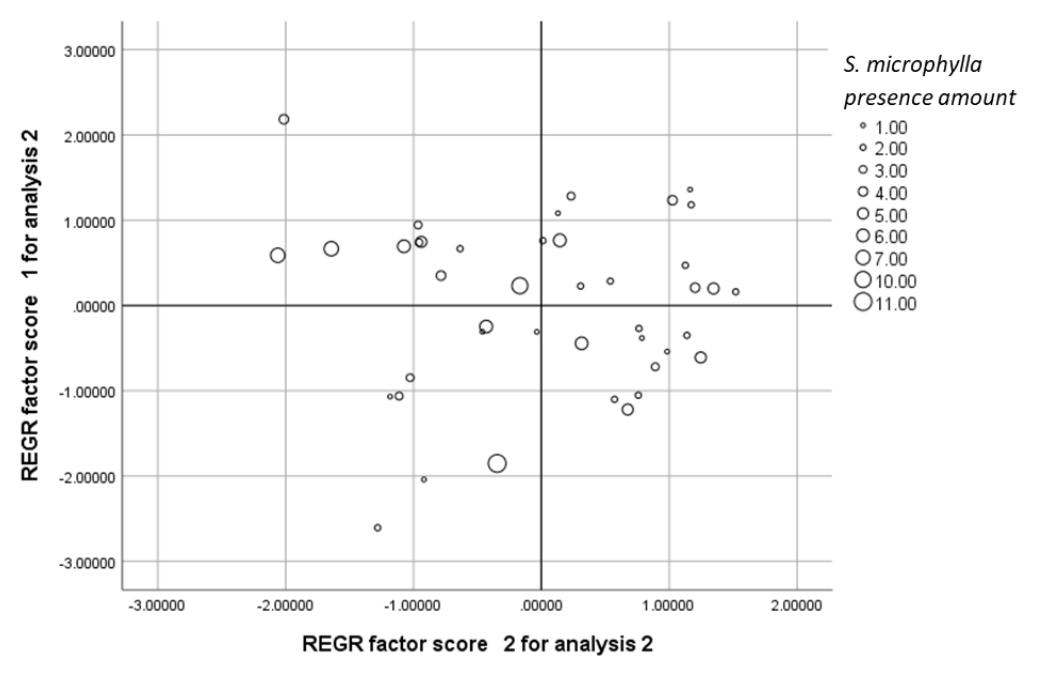

Figure 4. The distribution of $S$. microphylla on presence plots related to environmental factors interact. Circle with larger size indicate more S. microphylla in that environment condition

Saurauia microphylla has positive association with $B$. axinanthera and L. rubiginosa. But, this species has negative association with S. pendula 0.1219. Barbour et al. (1980) states positively association (significant) indicated both species produce a positive spatial relationship. Negative associations are interpreted to have a tendency to exclude one another or can mean different effects in the same environment (Whittaker and Likens (1975).

\section{Spatial distribution model of $S$. microphylla}

The results of the spatial distribution model analysis of S. microphylla are shown in Figure 5. The modeling results show that S. microphylla has a distribution on all slopes of Mount Slamet, but with a higher possibility on the southwestern slope.

The results of spatial distribution analysis of the model show training AUC of 0.988 can be seen in Figure 6. These values suggest that the results of the $S$. microphylla modeling can be categorized as accurate because it is almost close to the maximum value of 1 . The AUC value can be used to indicate the spatial distribution model accuracy (Lobo et al. 2008; Yudaputra 2020) and model performance level (Krzanowski and Hand 2009). The AUC value divided into several categories, i.e. 0.9-1 (excellent), 0.8-0.9 (good), 0.7-0.8 (fair), 0.6-0.7 (poor) and 0.5-0.6 (fail) (Krzanowski and Hand 2009). The number of Maxent simulations in this analysis was as many as 500 runnings to find one best model. The results of the analysis showed that from the 8 total parameters used in the Maxent modeling, there were 3 parameters that had the most influence on habitat suitability of $S$. microphylla, i.e. elevation with contribution value of $61.2 \%$, minimum temperature with $20.5 \%$ and aspect with $9.4 \%$. 
Table 3. Association of Saurauia microphylla with other species of trees

\begin{tabular}{|c|c|c|c|c|}
\hline Species & Family & Jaccard index & $\begin{array}{l}\text { Association } \\
\alpha 0.05\end{array}$ & Association type \\
\hline Bellucia axinanthera Triana. & Melastomataceae & 0.3333 & Significant & Positive \\
\hline Lepisanthes rubiginosa (Roxb.) Leenh. & Sapindaceae & 0.1628 & Significant & Positive \\
\hline Saurauia pendula Blume & Actinidiaceae & 0.1219 & Significant & Negatif \\
\hline Lithocarpus sundaicus (Blume) Rehder & Fagaceae & 0.3443 & Not significant & - \\
\hline Macropanax dispermus (Blume) Kuntze & Araliaceae & 0.2143 & Not significant & - \\
\hline Elaeocarpus stipularis Blume & Elaeocarpaceae & 0.1818 & Not significant & - \\
\hline Castanopsis argentea (Blume) A.DC. & Fagaceae & 0.0889 & Not significant & - \\
\hline Neolitsea cassiifolia Merr. & Lauraceae & 0.0698 & Not significant & - \\
\hline Pinus oocarpa Schiede & Pinaceae & 0.0476 & Not significant & - \\
\hline Myrsine avenis (Blume) A. DC. & Primulaceae & 0.0454 & Not significant & - \\
\hline Cyathea latebrosa (Wall. ex Hook.) Copel. & Cyatheaceae & 0.0425 & Not significant & - \\
\hline Pinus merkusii Jungh. et de Vriese & Pinaceae & 0.0377 & Not significant & - \\
\hline Lepisanthes amoena (Hassk.) Leenh. & Sapindaceae & 0.0238 & Not significant & - \\
\hline Litsea elliptica Blume & Lauraceae & 0.0238 & Not significant & - \\
\hline Magnolia candollei (Blume) H.Keng & Magnoliaceae & 0.0238 & Not significant & - \\
\hline Toona sureni (Blume) Merr. & Meliaceae & 0.0238 & Not significant & - \\
\hline Litsea firma (Blume) Hook.f. & Lauraceae & 0.0238 & Not significant & - \\
\hline Bischofia javanica Blume & Phyllanthaceae & 0.0227 & Not significant & - \\
\hline
\end{tabular}

Note: There are three significant association of tree species with $\alpha 0.05 ; \mathrm{df}=1$; Jaccard index showed the level of association $0-1$ (the maximum association level)

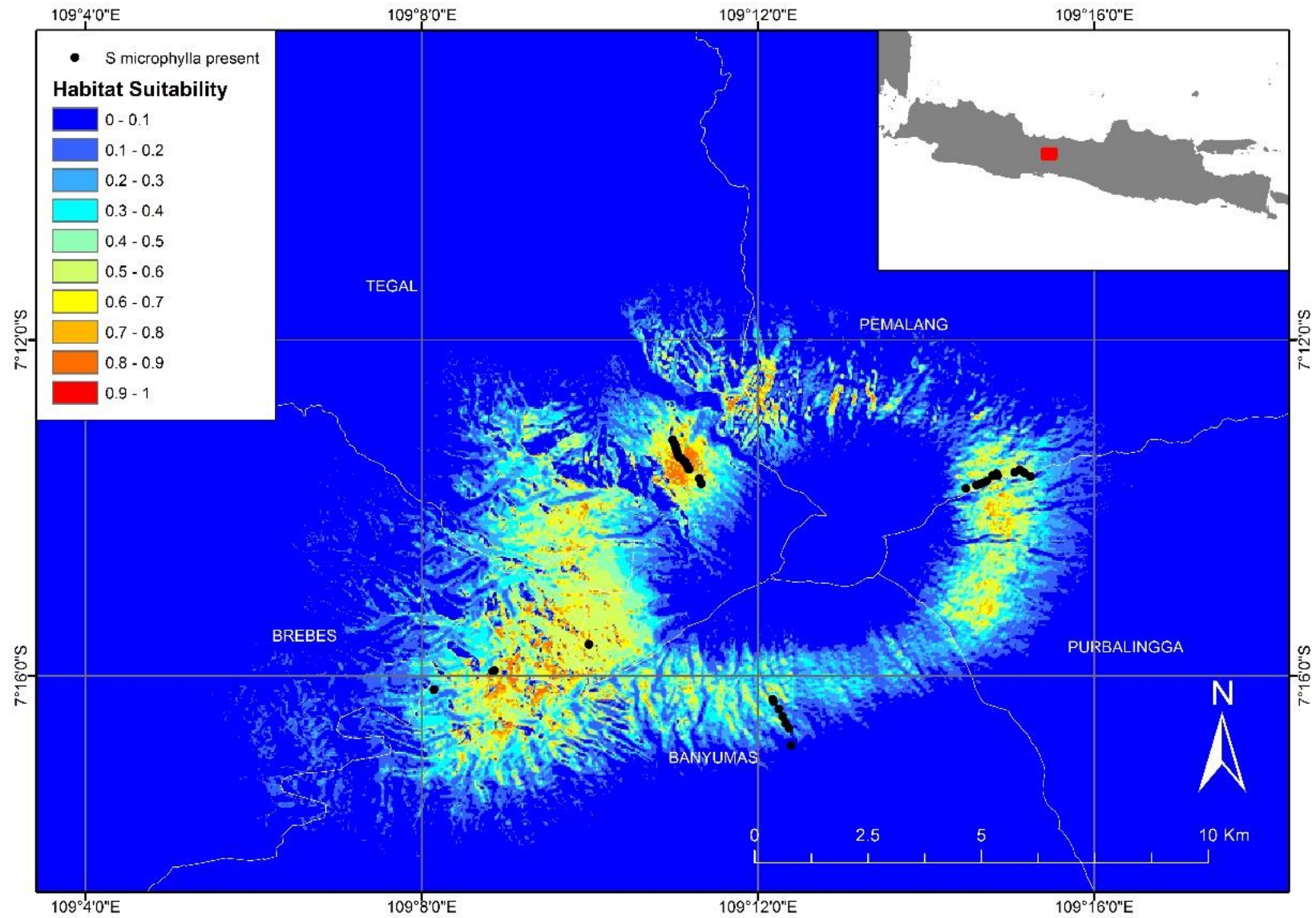

Figure 5. Spatial distribution model (or habitat suitability maps) of S. microphylla in Mount Slamet area, Central Java, Indonesia 


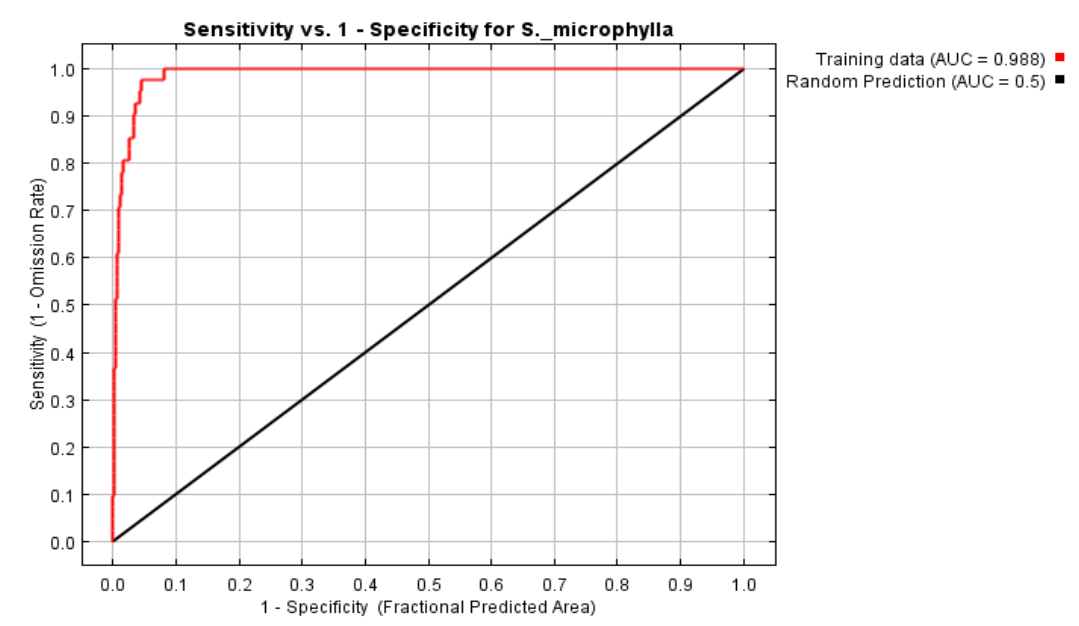

Figure 6. The Area Under the Curve (AUC) training score of S. microphylla

\section{Discussion}

This research strengthened the existing information that Mount Slamet is one of the natural distribution areas of $S$. microphylla in Indonesia. We revealed that the species were found in almost all directions on the slopes of the Mount Slamet region. In this study, a total of 145 individuals of S. microphylla was recorded in which the population was dominated by sapling phase. However, the population at trees and seedlings phases were rarely found, implying a deficiency in regeneration.

Local people around Mount Slamet recognized $S$. microphylla as umbel-umbelan in local names. Other communities in West Java, called S. microphylla and plants from the genus Saurauia as ki leho (Wihermanto 2004), those in Central Java and East Java called lotrok (Van Steenis 1972), pirdot in North Sumatra (Sitorus 2015), lempede in Borneo and soyogik in North Sulawesi (Kadji et al. 2013).

Environmental data from the 42 plots where $S$. microphylla recorded provided information about on habitat preference of the species. The population of $S$. microphylla was found in the forest at high altitude, ranged between 1689-2265 $\mathrm{m}$ asl. This is in accordance with the finding by Soemarno and Girmansyah (2012) which found S. microphylla in forest area of the Slamet Mountain at $1000-2500 \mathrm{~m}$ asl elevation. This result is also in line with Van Steenis (1972) which stated that in general the genus Saurauia live in upland forests with altitude of about 600$2100 \mathrm{~m}$ asl. Our study found that S. microphylla grew in a relatively sloping to steep terrain with slopes approximately $3-40^{\circ}$. Based on field observations, this species tended to grow on hillsides or valley floor. This result consistent to Van Steenis (1972) which stated Saurauia generally lives along a small river and the valley floor. S. microphylla was also found in locations with temperatures of $16-27.2^{\circ} \mathrm{C}$ during the day and air humidity of $49.3-90 \%$. The soil habitat of S. microphylla has $\mathrm{pH}$ of 5.8-7 with soil moisture of $15-70 \%$. This species can live in habitats with canopy cover between $0-92 \%$, suggesting that S. microphylla has high adaptability to light intensity.
The result of PCA on all observation plots (both presence and absence plots) showed two-factor interactions that influenced the presence of S. microphylla (Table 2). Altitude, soil $\mathrm{pH}$, and humidity were the first interaction factor, while slope and canopy cover was the second interaction factor. Further, the PCA results on the presenceonly plots showed the trend of S. microphylla distribution in which there was two interaction of factors that affect the distribution of species, i.e. humidity, slope and canopy as the first factor. The second factor is elevation and soil $\mathrm{pH}$.

The two PCA results suggest that the most influential factor in the presence and distribution of S. microphylla is elevation with a factor value of 0.844 and 0.829 , respectively. Our finding is in line with Robiansyah and Davy (2015) that reported elevation had an influence on the presence of Dipterocarpus littoralis along with litter thickness, litter cover, and slope factors. Elevation is one of the important factors in the distribution of several plant species (Kurniawan and Parikesit 2008), making it as the discriminant factor in classifying vegetation zones in the tropics (Dolezal and Srutek 2002). Elevation has a strong influence on the microclimate of habitat including light intensity, temperature, and air humidity (Kaufman 1989). Further analysis revealed that the presence and absence of S. microphylla from all 103 observation plots showed that this species had a tendency to live in an environment with high elevation approximately $1942.64 \pm 127.83 \mathrm{~m}$ asl and can survive in a higher soil $\mathrm{pH}$ (Table 1, Figure 3). These species were also found more in locations with lower air humidity had a tendency to appear at locations with slope approximately $24.45^{\circ} \pm 9.13^{\circ}$ and able to grow in denser canopy cover. When focusing on the presence-only plots (Figure 4), we found that larger population of $S$. microphylla grew on habitat with higher humidity and denser canopy cover. In addition, S. microphylla preferred habitats with more gentle slopes at lower elevations and lower $\mathrm{pH}$. Field observations indicate some S. microphylla individuals are able to live in the shade, under the other tree stands. 
The analysis of association shown that there were 18 tree species live around $S$. microphylla. The Chi-square test result showed that there were only 3 species had significant association at $95 \%$ confidence level, i.e. Bellucia axinanthera, Lepisanthes rubiginosa, and Saurauia pendula. The Jaccard index value indicates that the association of $S$. microphylla with Bellucia axinanthera can be classified as low with Jaccard index value of 0.333 , while the two other can be categorized as very low. In terms of the direction of association, S. microphylla had 2 positive associations and 1 negative association. Positive value association indicates that the species are dependent on each other (Whittaker and Likens 1975). In contrast, negative association is interpreted that the species have a tendency to exclude one another, or they respond differently in the same environment (Whittaker and Likens (1975). Morin (2011) mentioned that negative interactions between two or three species which live in the same niche or tropic level will tend to create interspecific competition, resulting in reduced abundance, decreased phenotype or some phenotypic components such as body size, growth rate, fertility or survival ability.

The result of the spatial distribution model of $S$. microphylla suggests that this species has predicted distribution on all slopes of Mount Slamet. Nonetheless, the distribution of $S$. microphylla is more dominated on the southwestern slope. It is because the southwestern slope has the most extensive area with altitudinal ranges most suited with $S$. microphylla habitat preference. It can be seen in Figure 1 that the western slopes towards the southwest have the most extensive areas with elevation of 1500-1800 $\mathrm{m}$ asl, while habitat suitability on the north is decreasing and becoming lower to the east and south slopes. The habitat suitability map of $S$. microphylla predicted using spatial modelling has a shape like a ring with a hole in the middle. The low suitability index around the middle hole, which is the area around the Mount Slamet pass, implies that $S$. microphylla has maximum elevation threshold to grow.

The results of spatial distribution analysis have AUC training value of 0.988 (Figure 6), suggesting the high accuracy in predicting the distribution area of $S$. microphylla. Elevation is the environmental factor with the highest contribution in prediction model with a contribution value of $61.2 \%$. This is consistent with the results of the PCA analysis which found that elevation is one of the factors that greatly influences to the distribution and presence of $S$. microphylla.

Based on the results above, the best conservation strategy to preserve $S$. microphylla is by creating zonebased conservation delimited according to the elevation. It means that areas with altitude of more than $1600 \mathrm{~m}$ asl need to be protected by stakeholders to prevent disturbances on S. microphylla habitat. Activities that are not in accordance with conservation principles and have the potential to cause habitat damage need to be suppressed, especially in the natural distribution area of S. microphylla with altitude of $1687-2265 \mathrm{~m}$ asl.

In conclusion, this research concludes that the total number of Saurauia microphylla found in the observation plots was 145 individuals consisting of 89 saplings, 39 poles, 14 trees, and 3 seedlings. The population of $S$. microphylla was found in forests with altitudinal ranges of $1689-2265 \mathrm{~m}$ asl and slopes of $3-40^{\circ}$. The species grows in a relatively cold climate with air humidity of $49.3-90 \%$. Soil in S. microphylla habitat has $\mathrm{pH}$ of approximately 5.87 with soil moisture between $15-70 \%$. It can grow on a wide range of light intensity indicated by canopy cover of $0-92 \%$ and. There were 18 tree species that grew around $S$. microphylla with three species have significant association with the species. Analysis of spatial distribution model shown that S. microphylla predicted to spread across all slopes of Mount Slamet with the southwestern slopes predicted has the most extensive habitat suitability areas.

\section{ACKNOWLEDGEMENTS}

The author would like to thank all those who fund and support this research. This research was funded by the SAINTEK Scholarship 2018 from the Indonesia Ministry of Research and Technology. We thank the Department of Biology, Faculty of Mathematics and Natural Sciences, Universitas Indonesia for guidance and direction. Thanks to HIBAH PITTA B Universitas Indonesia 2019 with the grant agreement number No: NKB-0651/UN2.R3.1 / HKP.05.00 / 2019. We acknowledge the Research Center for Plant Conservation and Botanic Gardens-Indonesian Institute of Sciences for support, guidance and assistance provided. Thank PERHUTANI Divre 1 for granting research location permits and Baturraden Botanic Garden for helping the research.

\section{REFERENCES}

Ahmed, Y, Rahman S, Akhtar P, Islam F, Rahman M, Yaakob Z. 2013. Isolation of steroids from n-hexane extract of the leaves of Saurauia roxburghii. Intl Food Res J 20 (5): 2939-2943.

Ahmed Y, Akhtar P, Rahman S, Yaakob Z. 2016. Chemical constituents of Saurauia roxburghii. Chem Nat Compd 52 (5): 953-955.

Barbour BM, Burk JK, Pitts WD. 1980. Terrestrial Plant Ecology. The Benjamin-Cummings, New York.

Briggs M. 2011. Saurauia (Actinidiaceae) of New Guinea: current status, future plans. Gard Bull Sing 63: 77-82.

Briggs M. 2015. A new name in New Guinea Saurauia Willd. (Actinidiaceae). Kew Bull 70: 50-51.

Conn BJ, Damas KQ. 2013. A new species of Saurauia (Actinidiaceae) from Papua New Guinea. Telopea 15: 9-12.

Dolezal J, Srutek M. 2002. Altitudinal changes in composition and structure of mountain-temperate vegetation: a case study from Western Carpathians. J Plant Ecol 158 (16): 201-221.

Dressler S, Bayer C. 2004. Actinidiceae in 6th series book "The Families and Genera of Vascular Plants". Springer-Verlag. Berlin.

Franklin SB, Gibson DJ, Robertson PA, Pohlmann JT, Fralish JS. 1995. Parallel analysis: a method for determining significant principal components. J Veg Sci 6:99-106.

Hutapea A, Hutahaen S, Ilyas S. 2018. Influence of pirdot leaf Saurauia vulcanii Korth extracts on the blood glucose rate and histologic description of the retina of male mice (Mus musculus Stain DDW). Asian J Pharmacceut Clin Res 11 (11): 389-392.

IUCN. 2020. The IUCN Red List of Threatened Species. Version 2019-3. http://www.iucnredlist.org. [11 March 2020].

Jongman RHG, ter Braak CJF, van Tongeren OFR. 1987. Data Analysis in Community and Landscape Ecology. Pudoc, Wageningen. 
Kadji MH, Runtuwene MRJ, Citraningtyas G. 2013. Phytochemical test and antioxidant activity of soyogik leaf ethanol extract (Saurauia bracteosa DC). Pharmacon 5 (1): 13-17.

Kaufman PB. 1989. Plants: Their Biology and Importance. Harper \& Row Publishers Inc, New York.

Keith BDA. 2000. Sampling designs, field techniques and analytical methods for systematic plant population surveys. Ecol Manag Restor 1 (2): 125-139.

Kent M, Coker P. 1992. Vegetation Description and Analysis: A Practical Approach. Belhaven Press, London.

Krzanowski, WJ, Hand DJ. 2009. ROC curves for continuous data Chapman and Hall, Boca Raton, FL.

Kurniawan A, Parikesit. 2008. Tree species distribution along the environmental gradients in Pananjung Pangandaran Nature Reserve, West Java. Biodiversitas 9 (4): 275-279.

Leathwick JR, Elith J, Hastie T. 2006. Comparative performance of generalized additive models and multivariate adaptive regression splines for statistical modelling of species distributions. Ecol Model 199: 188-196.

Lobo JM, Jiménez-Valverde A, Real R. 2008. AUC: a misleading measure of the performance of predictive distribution models. Glob Ecol Biogeogr 17: 145-151.

Ludwig JA, Quartet L, Reynolds JF. 1988. Statistical ecology: a primer in methods and computing (Vol. 1). John Wiley \& Sons, New York.

Morin PJ. 2011. Community ecology 2nd edition. Blackwell Publishing Ltd, West Sussex, UK.

Muaja AD, Koleangan HSJ, Runtuwene MRJ. 2013. Toxicity test through BSLT method and phytochemical content analysis of soyogic leaf extract (Saurauia bracteosa DC.) through Soxhletation method. J Nat Prod 2 (2): 115-118.

Mueller-Dombois D, Ellenberg H. 1974. Aims and methods of vegetation ecology. Blackburn Press Caldwell. New Jersey.

Peres-Neto PR, Jackson DA, Somers KM. 2003. Giving meaningful interpretation to ordination axes: Assessing loading significance in principal component analysis. Ecology 84 (9): 2347-2363.

Purnomo DW, Magandhi M, Kuswantoro F, Risna RA, Witono JR. 2015. Developing Plant Collections on the Regional Botanic Gardens in Framework of Plant Conservation Strategy in Indonesia. Buletin Kebun Raya 18 (2): 111-124. [Indonesian]

Rafidah AR. 2013. Actinidiaceae. In: Kiew R, Chung RCK, Saw LG, Soepadmo E (eds.). Flora of Peninsular Malaysia Series II: Seed Plants. Forest Research Institute, Kuala Lumpur.
Robiansyah I, Davy AJ. 2015. Population status and habitat preferences of critically endangered Dipterocarpus littoralis in West Nusakambangan, Indonesia. Makara J Sci 19 (4):150-160.

Sala OE, Chapin FS, Armesto JJ, Berlow E, Bloomfield J, Dirzo R, Huber-Sanwald E, Huenneke LF, Jackson RB, Kinzig A, Leemans R, Lodge DM, Mooney HA, Oesterheld M, Poff NL, Sykes MT, Walker BH, Walker M, Wall DH. 2000. Global Biodiversity Scenarios for the Year 2100. Science 287: 1770-1774.

Sitorus P. 2015. Characterization simplisia and ethanolic extract of pirdot (Saurauia vulcanii Korth) leaves and study of antidiabetic effect in alloxan-induced diabetic mice. Intl J ChemTech Res 8 (6): 789-794.

Soemarno S, Girmansyah D. 2012. The Condition of Nature Forest Area of Slamet Mountain, Central Java. In: Maryanto I, Noerdjito M, Partomihardjo T. Ekologi Gunung Slamet. LIPI-Unsoed, Purwokerto. [Indonesian]

Takeuchi W. 2008. Saurauia taylorii (Actinidiaceae), a distinctive new species from the Kaijende High-lands of Papua New Guinea. Blumea 53: 335-340.

Van Steenis CGCJ. 1972. The Mountain Flora of Java. Brill, Leiden.

Vukadinovic D, Sutawidjaja I. 1995. Geology, mineralogy and magma evolution of Gunung Slamet Volcano, Java, Indonesia. J Southeast Asian Earth Sci 11 (2): 135-164.

Walter KS, Gillett HJ. 1998. IUCN Red List of Threatened Plants. Compiled by the World Conservation Monitoring Centre. IUCN-The World Conservation Union, Gland, Switzerland and Cambridge.

Whittaker RH, Likens GE. 1973. Primary production: the biosphere and man. Human Ecol 1 (4): 357-369.

Wihermanto. 2004. Dispersion pattern interspecific association and population status of threatened plants on submontane and montane zones of Mount Gede-Pangrango National Park. Biodiversitas 5 (1): 17-22.

Worldclim. 2020. Version-2 WorldClim-Global Climate. http://worldclim.org/version2. [15 January 2020].

Yudaputra A. 2020. Modelling potential current distribution and future dispersal of an invasive species Calliandra calothyrsus in Bali Island, Indonesia. Biodiversitas 21 (2) 674-682.

Zulkarnaen RN, Nisyawati, Witono JR. 2019. Population study and habitat preferences of Pinang Jawa (Pinanga javana) in Mt. Slamet, Central Java, Indonesia. Biodiversitas 20 (3): 712-718. 